\title{
Demographic Variables of University Teachers and Usage of Electronic Information Resources: A Case in Sri Lanka
}

\author{
Nadarajah Sivathaasan ${ }^{1}$, Sivapalan Achchuthan ${ }^{1} \&$ Rasendram Kajananthan ${ }^{1}$ \\ ${ }^{1}$ University of Jaffna, Sri Lanka \\ Correspondence: Nadarajah Sivathaasan, Main Library, University of Jaffna, Sri Lanka. E-mail: \\ sivathas27@gmail.com
}

Received: July 8, 2013

Accepted: August 23, 2013

Online Published: September 18, 2013

doi:10.5539/ijbm.v8n19p90

URL: http://dx.doi.org/10.5539/ijbm.v8n19p90

\begin{abstract}
The primary aim of the study is to identify whether there are any significant mean differences among demographic variables such as gender, age group, faculty, teaching language and experience of university teachers employed at the University of Jaffna, Sri Lanka on the usage of electronic information resources (EIR). The study employs independent samples t- test and one-way ANOVA (f-test) to test the operational hypotheses. The survey method used in this study is a questionnaire and a total of 75 usable responses were obtained using stratified random sampling technique. The t-test revealed a statistically significant difference between the mean number of usage of electronic information resources and gender $(t=5.099, p<0.05)$ with the highest mean value of male university teachers. According to the f-test, there are significant mean differences among age group, teaching language and experiences of teachers on the usage of electronic information resources, whereas mean usage of electronic information resources do not differ significantly among five different faculties $(\mathrm{F}=$ $2.075, \mathrm{p}>0.05$ ). This study would hopefully benefit to the academicians, researchers, policy makers, and practitioners of Sri Lanka as well as other countries.
\end{abstract}

Keywords: demographic variables, university teachers, Electronic Information Resources (EIR)

\section{Introduction}

In the 21 st century, advancement of computer and networking technologies had revolutionized information usage and access across the globe in a systematic way. In this context, electronic information resources (EIR) like e-books, digital libraries, online journal, magazine, e-learning tutors, on line test e-journals, e-discussions, e-news, data archives and e-mail on line chatting can be accessed through computers or other electronic devices directly connected to the computer such as a CD-ROM drive or remotely via network such as the internet. This usage has increased the global dissemination of information. Due to this, Universities in Sri Lanka should utilize the communication infrastructure to take the advantages in teaching and learning methodologies in the higher studies. New modes of accessing information have emerged as a result of the Internet and World Wide Web. This has been profound, especially on academic institutions (Gakibayo, Odongo, \& Obura, 2013). Further, Recent global advances in communications infrastructure, digital media, network services, and electronic commerce present transformational opportunities and fundamental challenges for libraries. Developments in these areas appear to offer opportunities for increasing and enhancing library service offerings, reducing costs, and for improving organizational performance (Young, 2001).

In general, users can access EIR from a library, student IT centre, internet cafe, work place, and home. University teachers and students therefore are able to access up-to-date international literature as soon as it is published on the Internet. This usage has made changes in the role of traditional library services and influenced the way the academicians and researchers work. Further, electronic information in Sri Lankan University libraries is evolved from print materials to electronic information materials and services in the form of CD-ROMS, e-books, e-databases, electronic journals, electronic current awareness service and information subject gateways, accessed through the internet (Gakibayo et al., 2013). Electronic information resources are considered as an indispensable tool for scholarly work. These provide high quality information services in support of teaching and research for academic staff members as well as acquisition of knowledge of the students. In this way, Mission statement of the University of Jaffna is viewed to be a leading center of academic excellence in producing intellectual, professionally competent and capable graduates by providing quality 
teaching, learning, and carrying out research to meet the emerging needs of the national and international community with special emphasis on the social, economical and cultural needs of northern Sri Lanka. In this context, these resources are an integral part of universities and have a critical role to play in supporting the core mission of the university that is teaching, learning, and research.

Therefore, the study on Demographic Variables of University Teachers and Usage of Electronic Information Resources (EIR) can provide the support to the strategic decision making in intellectual and human capital development.

\subsection{Research Question}

What extent do the demographic variables of the university teachers influence on the usage of electronic information resources?

\subsection{Objective of Study}

This study identifies two main objectives relating to demographic variables and usage of electronic information resources (EIR).

To compare the significant mean differences between the usage of electronic information resources (EIR) across the demographic variables of university teachers such as gender, faculty, age group, language in which lecture is taken, experience.

To provide suggestion on how to improve the usage of electronic information resources (EIR) among university teachers.

\section{Review of Literature and Hypotheses Development}

It is increasingly an important function of electronic information resources today to provide information in electronic formats including indexes, full-text articles, complete journals, and web resources. Electronic information has gradually become a major resource in every university across the globe. The emergence of electronic information resources has tremendously transformed information handling and management in academic environments. Further, researchers and scholars utilize the electronic resources in the academic perspective (Shuling, 2007). The new trend in the use of technology is the adoption of digital libraries for research activities. Information and communication technologies have revolutionized the concept of libraries. Students and academics will benefit from an effective digital library as it will provide a combination of digitally delivered content with learning support and services in the teaching and research activities (Mufutau, Afolake, \& Oluwadamilare, 2012).

Personal demographic variables have the influence on the usage of electronic Information Resources (EIR). In this context, scholars found that, personal demographic variables as age, income level, gender, professional qualification, country level have the influential role on the usage of the EIR (Mufutau et al., 2012; Goodson, McCormick \& Evans, 2001; Bimber, 2000; Abu Qudais, Al-Adhaileh, \& Al-Omaril , 2010). Gakibayo et al. (2013) have jointly focused on the study in the concept as utilization of electronic information resources in Mbarara University Library. Both quantitative and qualitative methods were employed to elicit data from library staff and undergraduate students from four faculties of Mbarara University. Two hundred and sixty six respondents participated in the particular study. Data was collected by use of questionnaires, document analysis and interview guide. The study found that utilization of e- resources was not only affected by lack of computer skills and information literacy skills but also lack of enough computers and slow internet connectivity. The frequency of use of these resources indicated that a lot need to be done to increase e-resource use.

Mufutau et al. (2012) focused the study on the influence of demographic factors on the use of digital library by the post graduate students in private universities in Nigeria. This particular study used the survey research approach, which is the description of the influence of demographic factor on the use of digital libraries by postgraduate students in private universities. The study found out that there is a significant difference in the level of income of students from both universities in relation to the use of digital resources. It also reveals that gender has no significant influence on digital resources usage meanwhile there is a significant influence of program of study on student use of digital resources. Women are likely to be infrequent users, and more likely to be intermediate users and that females are less intensive internet users than males (Bimber, 2000). Further, Male college students are more likely than their female counterparts to use the Internet for recreational purposes as playing games online, visiting adult-only sites, gambling, accessing news groups and discussion forums, seeking information for personal use etc. While females are more likely to use the Internet to talk to family and friends (Goodson et al., 2001). 
Korobili, Tilikidou \& Delistavrou (2006) conducted the study on factors that influence the use of library resources by faculty members. A census survey, using a structured questionnaire, among the faculty of the Technological Educational Institute of Thessaloniki was conducted to examine the frequency. The great majority of the faculty members uses printed sources more than e-sources, but they also use e-sources quite frequently. Use is mostly of books, websites, and printed journals. It was also found that the use of e-sources is higher in the School of Business Administration and Economics among those who hold a $\mathrm{PhD}$ degree and among younger members of the faculty. Also, the results indicated that the use of e-sources is positively influenced by the respondents' perceived usefulness of resources, the convenience of access to the sources and their academic productivity.

Abu Qudais et al. (2010) have jointly focused on senior faculty members' attitudes in Jordanian Universities towards using information and communication technology. Researchers found that, the seniors' attitude towards information communication technology is clearly positive and most of them willing to be trained to practice that. Results indicated no significant differences in senior faculty members attitudes toward ICTs related to their gender, college, experience, university, and country of PhD. Musa and Emmanuel (2011) jointly found that there exists statistical difference between male and female students with higher mean value of males. A study by Amkpa (2007) revealed that male and female students differ significantly in attitudes towards computer applications which later affect their job opportunities after graduation. Findings of Manda \& Mukangara (2007) revealed that gender is associated with the use of electronic information resources and male postgraduate students were more likely to use electronic information resources than female students. Gender is a relevant factor in examining use of electronic sources. Sacks \& Bellissimo (1993), Dyck \& Smither (1994), Koohang (1986), found that neither age nor gender was seriously correlated to computer anxiety, computer confidence or liking but that computer experience was. However, sex seems to affect electronic information sources use.

Several studies focused on the usage of electronic information resources and performance. In relation to this, Sivathaasan and Velnampy (2013) carried out a study on use of electronic information resources and academic performance of university teachers. The results indicated that usage of electronic information resources has a strong positive association with academic performance $(\mathrm{r}=0.623, \mathrm{p}<0.01)$ and it has an impact on academic performance at the rate of $38.8 \%\left(\mathrm{R}^{2}=0.388\right)$ according to regression analysis. Focusing on demographic variables, Velnampy (2006) analyzed the association among personal demographic variables and incentive systems in Sri Lanka and concluded that there is a significant difference on gender group, educational qualification, status, and monthly income on the perceived level of rewards.

The following null hypotheses with respect to demographic variables were formulated for the purpose of this research.

$\mathrm{H}_{\mathrm{o} 1}$ - There is no significant mean difference between the perception of male and female university teachers and the usage of electronic information resources (EIR).

$\mathrm{H}_{02}$ - There is no significant mean difference on the usage of electronic information resources (EIR) among five different faculty members.

$\mathrm{H}_{03}$ - There is no significant mean difference between age group of the teachers and usage of electronic information resources (EIR).

$\mathrm{H}_{04}$ - There is no significant mean difference on usage of electronic information resources (EIR) between university teachers who teach in English and who do not.

$\mathrm{H}_{\mathrm{o5}}$ - There is no significant mean difference on usage of electronic information resources (EIR) between the university teachers who have experience and have not experience.

\section{Methodology}

Research design is a conceptual structure within which the research has to be conducted. A well-planned research design will facilitate the collection of relevant evidence and information for the research, efficiently (Kothari, 1990). This study was conducted during March to April 2013 in the University of Jaffna and the participants invited to participate in the research were the academicians. The population consisted of two hundred and ninety four (294) university teachers as per the database given by the Academic Establishment Branch, University of Jaffna on $5^{\text {th }}$ April 2013 and stratified into five groups, which is given in table 1. 
Table 1. Total number of university teachers

\begin{tabular}{ccc}
\hline No & Faculties & Total Population \\
\hline 1 & Faculty of Agriculture & 22 \\
2 & Faculty of Arts & 124 \\
3 & Faculty of Management Studies \& Commerce & 31 \\
4 & Faculty of Medicine & 46 \\
5 & Faculty of Science & 71 \\
& Total Number of University Teachers & $\mathbf{2 9 4}$ \\
\hline
\end{tabular}

The sampling technique used in this research was stratified random sampling technique, as this study was limited to the university teachers, employed at the University of Jaffna, Sri Lanka. Thus, it was decided to collect data from each of the five faculties in proportion to the actual size in the total population. Following table shows the sample size determined for the purpose of data collection.

Table 2. Number of teachers selected as a sample

\begin{tabular}{cccc}
\hline No & Faculties & Total Population & Sample Size \\
\hline 1 & Faculty of Agriculture & 22 & 7 \\
2 & Faculty of Arts & 124 & 42 \\
3 & Faculty of Management Studies \& Commerce & 31 & 11 \\
4 & Faculty of Medicine & 46 & 16 \\
5 & Faculty of Science & 71 & 24 \\
& Total Number of University Teachers & 294 & $\mathbf{1 0 0}$ \\
\hline
\end{tabular}

Survey method is a significant way of gathering information (Fei, 2006). By carefully following certain scientific procedures, one can make inferences about a large group of elements by studying a relatively small number selected from the larger group (Powell, 1997). In this study, the survey method is a questionnaire which pleads for data from university teachers. Seventy five (75) questionnaires were selected and used for research purposes (yielding a response rate of 75 per cent). Table 3 provides a summary of respondents who returned the questionnaires.

Table 3. Number of respondents by faculty and gender wise

\begin{tabular}{ccccc}
\hline No & Faculties & Male & Female & Total \\
\hline 1 & Faculty of Agriculture & 4 & 3 & 7 \\
2 & Faculty of Arts & 12 & 18 & 30 \\
3 & Faculty of Management Studies \& Commerce & 6 & 3 & 9 \\
4 & Faculty of Medicine & 4 & 6 & 10 \\
5 & Faculty of Science & 10 & 9 & 19 \\
& Total Number of Respondents & $\mathbf{3 6}$ & 39 & 75 \\
\hline
\end{tabular}

Research instrument titled "Demographic Variables of University Teachers and Usage of Electronic Information Resources (EIR): a case in Sri Lanka" uses a five-point likert scale ranging from strongly agree to strongly disagree. Self-administered questionnaire which was developed as a tool for data collection is composed of two parts such as Part A and Part B. Part A of the questionnaire has the demographic variables of the university teachers, which consist of name of the faculty in which they are working, gender, marital status, age group, designation, experience, monthly earnings, language in which they are teaching and academic qualifications. Part B is used to find out the use of electronic information resources which consist of ten statements measured based on the above scale.

The first five responses were treated as a pilot study which was excluded by the researcher. Primary and secondary data are used for the study. Primary data have been collected through the questionnaire, and 
secondary data collected from the books, journals, magazines, etc. Various Statistical methods have been employed to compare the data collected from 75 respondents. These methods include Reliability analysis, One sample Kolmogorov-Smirnov test, Independent samples t- test and One - way Anova (f-test). "SPSS" (Statistical Package for Social Science) 16.0 version has been used to analyze the data.

\section{Results and Discussion}

\subsection{Test of Reliability and Normality}

Reliability test was performed on each variable to determine the internal consistency. The results in Table 4 show that values of the Cronbach's alphas are all in excess of 0.7 (a value in the range of 0.70 is reliable, Nunally \& Bernstein, 1994), indicating that variables used in this study deemed to have adequate reliability and can be used for further analysis.

Table 4(a). Test of reliability

\begin{tabular}{ccc}
\hline Variables & No of Elements & Alpha Coefficient Value(s) \\
\hline Usage of EIR & 10 & .768 (overall) \\
Usage of EIR & 10 & Ranging from .712 to .799 (individual) \\
\hline
\end{tabular}

A test of normality (one sample Kolmogorov-Smirnov test) was carried out to identify whether the sample cumulative distribution function for a field is homogenous with a normal distribution. In this study, this test was done on the distribution of respondents' scores. The results are shown in table 4(b).

Table 4(b). Test of normality

\begin{tabular}{ccc}
\hline Variables & Test Statistics (Kolmogorov-Smirnov & Probability Value (2-tailed) \\
\hline Element 1 & 2.902 & .000 \\
Element 2 & 2.497 & .000 \\
Element 3 & 2.618 & .000 \\
Element 4 & 1.490 & .024 \\
Element 5 & 1.735 & .005 \\
Element 6 & 2.821 & .000 \\
Element 7 & 2.116 & .000 \\
Element 8 & 1.838 & .002 \\
Element 9 & 2.619 & .000 \\
Element 10 & 1.767 & .004 \\
\hline
\end{tabular}

a. Test distribution is Normal.

It can be seen that scores for the usage of electronic information resources are significant at the 0.05 levels where $\mathrm{p}$-value is less than $0.05(\mathrm{P}<0.05)$. Hence, normality is assumed and the usage of EIR is normality distributed.

\subsection{Independent Samples T-Test}

In this study, Independent Samples t-test was performed to find out the significant mean different between the perception of male and female university teachers and the use of electronic information resources (EIR).

Table 5(a). Descriptive statistics for male and female teachers

\begin{tabular}{llllcc}
\hline \multirow{3}{*}{ Usage of EIR } & Gender & $\mathbf{N}$ & Mean & Std. Deviation & Std. Error Mean \\
\cline { 2 - 6 } & Male & 36 & 3.7472 & .36134 & .06022 \\
& Female & 39 & 3.1231 & .66549 & .10656 \\
\hline
\end{tabular}


Table 5(b). Inferential statistics for male and female teachers

\begin{tabular}{lllll}
\hline \multicolumn{5}{c}{ t-test for Equality of Means } \\
\hline T-test Variable & t-value & df & P-Value (2-tailed) & Mean Difference \\
\hline Usage of EIR & 5.099 & 73 & .000 & .62415 \\
\hline
\end{tabular}

According to table $5(\mathrm{a} \& \mathrm{~b})$, there are 36 male teachers with the average, 3.7472 usage of EIR, while university has 39 female teachers with the average, 3.1231 usage of EIR. As $p$ value is less than the $\alpha$, null hypotheses $\left(\mathrm{H}_{\mathrm{ol}}\right)$ is rejected. It means that $\mathrm{t}$ test revealed a statistically difference between the mean number of usage of EIR that male teachers have $(\mathrm{M}=3.7472, \mathrm{~s}=.36134)$ and female teachers have $(\mathrm{M}=3.1231, \mathrm{~s}=.66549), t(73)=5.099$, $p=.000, \alpha=.05$.

\subsection{One-Way ANOVA (f-test)}

The one - way Anova (f-test) was carried out to find out the significant mean different on the usage of electronic information resources among faculties, age group, language in which lecture is taken and experience of the teachers.

Table 6(a) provides the results of f-test carried out to indentify the mean difference between faculties and usage of EIR.

Table 6(a). Results of F-test - faculties vs usage of EIR

\begin{tabular}{cccccc}
\hline Description & Sum of Squares & df & Mean Square & F & Sig. \\
\hline Between Groups & 3.041 & 4 & .760 & 2.075 & .093 \\
Within Groups & 25.650 & 70 & .366 & - & - \\
Total & 28.691 & 74 & - & - & - \\
\hline
\end{tabular}

According to the test, the mean usage of EIR do not differ significantly among five different faculties $(\mathrm{F}=2.075$, $p>0.05)$. That's, the f-test failed to reveal a statistically reliable difference between the mean numbers of usage of EIR among faculties. Hence, the null hypothesis (Ho2) is accepted.

Table 6(b) summarizes the output of mean difference between age group of the teachers and usage of electronic information resources (EIR).

Table 6(b). Results of F-test - age group vs usage of EIR

\begin{tabular}{lccccc}
\hline \multicolumn{1}{c}{ Description } & Sum of Squares & df & Mean Square & F & Sig. \\
\hline Between Groups & 4.218 & 3 & 1.406 & 4.079 & .010 \\
Within Groups & 24.474 & 71 & .345 & - & - \\
Total & 28.691 & 74 & - & - & - \\
\hline
\end{tabular}

According to the above table, the significant level is less than the 0.05 levels $(\mathrm{P}<0.05)$. It means, f-test revealed that there is a significant mean difference between age group on the usage of EIR. Hence, null hypothesis $\left(\mathrm{H}_{03}\right)$ is rejected. Further, from the mean for each level of age group, teachers below 35 years old have the highest mean usage of EIR $(M=3.728)$, while teachers between $45-55$ years old have the lowest $(M=3.000)$.

Mean difference between the usage of electronic information resources (EIR) and university teachers who teach in English and who do not is given in table 6(c). 
Table 6(c). Results of F-Test - teaching language vs usage of EIR

\begin{tabular}{cccccc}
\hline Description & Sum of Squares & df & Mean Square & F & Sig. \\
\hline Between Groups & 4.511 & 2 & 2.256 & 6.717 & .002 \\
Within Groups & 24.180 & 72 & .336 & - & - \\
Total & 28.691 & 74 & - & - & - \\
\hline
\end{tabular}

Results indicated that there is a statistically significant mean difference among teaching languages such as English and Tamil $(\mathrm{F}=6.717, \mathrm{p}<0.05)$. Hence, null hypothesis $\left(\mathrm{H}_{04}\right)$ is rejected. This can also be explained by the mean plot in the f-test.

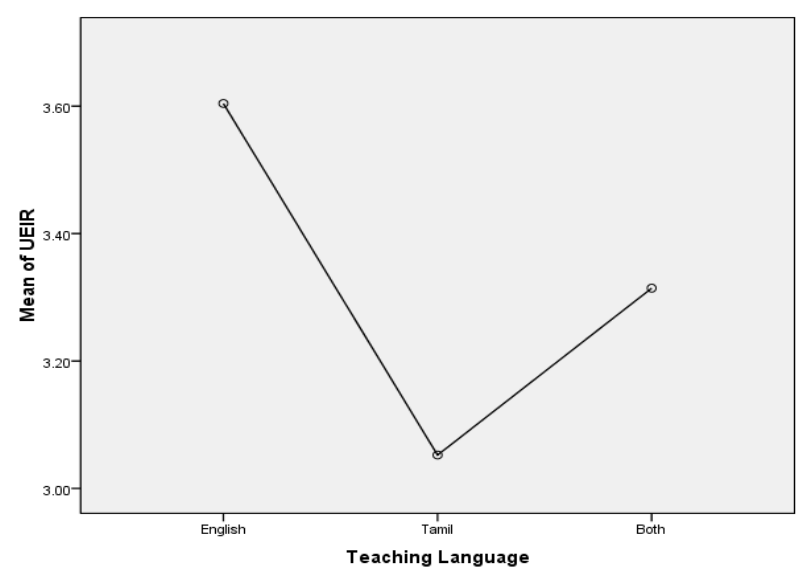

Figure 1. Mean plot-teaching language vs usage of EIR (UEIR)

The figure 1 shows that the teachers who deliver their lectures in English medium have the highest mean usage of EIR which is approximately 3.604. Mean value 3.052 is the lowest mean value, where Tamil is medium of instruction.

Output of mean difference on usage of electronic information resources (EIR) between the university teachers who have experience and have not experience is shown in table 6(d).

Table 6(d). Results of F-test - experience vs usage of EIR

\begin{tabular}{lccccc}
\hline \multicolumn{1}{c}{ Description } & Sum of Squares & df & Mean Square & F & Sig. \\
\hline Between Groups & 9.285 & 5 & 1.857 & 6.603 & .000 \\
Within Groups & 19.406 & 69 & .281 & - & - \\
Total & 28.691 & 74 & - & - & - \\
\hline
\end{tabular}

F-test clearly indicated that there is a significant mean difference between usage of EIR and experiences of the teachers, as $\mathrm{p}$ value is less than 0.05 levels $(\mathrm{F}=6.603, \mathrm{p}<0.05)$. Hence, null hypothesis $\left(\mathrm{H}_{05}\right)$ is rejected. The table 6(e) explains the mean difference between all six of the levels. 
Table 6(e). Descriptive statistics - experience vs usage of EIR

\begin{tabular}{ccccc}
\hline Experience & $\mathbf{N}$ & Mean & Std. Deviation & Std. Error \\
\hline Less than 3 years & 25 & 3.8120 & .33705 & .06741 \\
3 to 5 years & 13 & 3.2538 & .17614 & .04885 \\
$\mathbf{5}$ to 10 years & 6 & 3.8833 & .45789 & .18693 \\
$\mathbf{1 0}$ to 15 years & 18 & 3.0778 & .90395 & .21306 \\
15 to 20 years & 5 & 2.8800 & .44385 & .19849 \\
Above 20 years & 8 & 3.2500 & .28785 & .10177 \\
$\quad$ Total & 75 & 3.4227 & .62267 & .07190 \\
\hline
\end{tabular}

\section{Conclusion}

University teachers generally access all types of electronic information resources as on-line resources, in-house library databases, email, and websites. In this way, influence of demographic variables such as gender, faculty, age group, teaching language and experience of the university teachers on the usage of electronic information resources has been analyzed using independent samples t-test and the one-way ANOVA (f-test). The results of the t-test indicated that there is a statistically significant mean difference between the mean numbers of usage of electronic information resources and male and female university teachers $(t=5.099, p<0.05)$. Compared to female university teachers, male have the highest mean usage of electronic information resources. This finding is in line with what was previously reported by Musa \& Emmanuel (2011), Manda \& Mukangara (2007), and Amkpa (2007). On the other hand, findings of Mufutau et al. (2012), Abu Qudais et al. (2010) do not agree with the researchers. But, Bimber (2000) noted that male students are very intensive to use the Internet compared to female students in a supporting manner.

Findings from the one-way ANOVA (f-test) revealed that usage of electronic information resources differs significantly among age group, teaching language and experience of the university teachers $(p<0.05)$.In terms of age group, teachers less than 35 years old have higher usage compared to other age group as group between $35-45$ years, group between $45-55$ years and over 55 years. This finding is not in line with the findings of Sacks and Bellissimo (1993), Dyck and Smither (1994), Koohang (1986). Because, they revealed that age was not seriously correlated to electronic applications. University teachers who deliver lectures in English medium have the highest mean usage of electronic information resources $(\mathrm{M}=3.604)$.

As far as teaching experience is concerned, those who have teaching experience between 10 to 15 years showed higher mean usage of electronic information resources which is approximately 3.883 . This finding is not confirmed with findings of Abu Qudais et al. (2010), as they indicated insignificant difference related to experience. In a supportive way, Sacks and Bellissimo (1993), Dyck and Smither (1994), Koohang (1986) noted that experience is related to the electronic applications. Moreover, among five difference faculties mean usage of electronic information resources do not differ significantly $(\mathrm{p}>0.05)$, whereas mean usage of electronic information resources ranges between 3.19 and 3.73. This finding is corroborated with Abu Qudais et al. (2010)'s findings.

As revealed by the researchers, significant mean differences have been observed on the usage of electronic information resources among personal variables. Hence, awareness session and training courses necessary to handle the electronic information resources should be organized periodically by hiring experts as a means of improving the usage of electronic information resources, which ultimately assist to the academic excellence. In this connection, polices relating to the procurement of sophisticated technological equipments at no cost for the usage by university teachers should also be established. In addition, some of useful electronic information resources available on the web require annual subscriptions. Therefore, institutions should concentrate on the fund allocation or try to purchase those resources necessary to the intellectual and human capital development.

\section{References}

Abu Qudais, M., Al-Adaile, H. M., \& Al-Omari, A. (2010). Senior faculty members' attitudes in Jordanian universities towards using information and communication technology. International Arab Journal of e-Technology, 1, 135-141.

Adio, G., \& Popoola, S. O. (2010). Job satisfaction and career commitment of librarians in federal university libraries in Nigeria. Library Review, 59(3), 175-184. http://dx.doi.org/10.1108/00242531011031160

Amkpa, S. A. (2007). Gender and age difference in computer use and attitude among students of University of Maiduguri. The Information Technologists, 4(1), 60-67. 
Bimber, B. (2000). Measuring the gender gap on the Internet. Social science Quarterly, 81(3), 868-876.

Dyck, J. L., \& Smitter, J. A. (1994). Age difference in computer anxiety: the role of computer experience, gender, and education. Journal of Education Computing Research, 10(3), 239-248. http://dx.doi.org/10.2190/E79U-VCRC-EL4E-HRYV

Fei, Y. (2006). Users' emotional and material satisfaction at the micro/macro levels in an academic library. Pittsburgh: University of Pittsburgh. PhD thesis.

Gakibayo, A., Ikoja-odongo, J. R., \& Okello-Obura, C. (2013). Electronic Information Resources utilization by students in MBARARA university library. Retrieved from $\mathrm{http}: / /$ digitalcommons.unl.edu/cgi/viewcontent.cgi?article=2055\&context=libphilprac

Goodson, P., McCormick, D., \& Evans, A. (2001). Searching for sexually explicit materials on the Internet: An exploratory study of college students' behavior and attitudes. Archives of Sexual Behavior, 30(2), 101-118. http://dx.doi.org/10.1023/A:1002724116437

Koohang, A. A. (1986). Effects of Age, gender, college status, and computer experience on attitude towards library computer systems (LCS). Library and Information Research, 8, 349-355.

Korobili, S., Tilikidou, I., \& Delistavrou, A. (2006). Factors that influence the use of library resources by faculty members. Library review, 55(2), 91-105. http://dx.doi.org/10.1108/00242530610649594

Kothari, C. R. (1990). Research Methodology method \& Techniques (2nd ed.). New Delhi: New Age International (P) Ltd.

Lee, G. T., Dahlan, N., Ramayah, T., Karia, N., \& Hasmi, A., Hassan, A. M. (2005). Impact of interface characteristics on digital libraries usage. Malaysian Online Journal of Instructional Technology, 2(1), 1-9.

Manda, P. A., \& Mukangara, F. (2007). Gender analysis of electronic information resource use: The case of the University of Dar Es Salaam, Tanzania. University of Dar es Salaam Library Journal, 9(1), 31-52.

Mufutau, D. A., Afolake, O. R. O., \& Oluwadamilare, I. R. (2012). Influence of demographic factors on the use of digital library by the post graduate students in private Universities: a case study of Babcock and covenant University in Ogun State. Information and Knowledge Management, 2(5), 10-18.

Musa, D. B., \& Emmanuel, C. (2011). Gender differences in use of electronic resources in University Libraries of Adamawa State, Nigeria. Library Philosophy and Practice. Retrieved from http://unllib.unl.edu/LPP/

Nunally, J. C., \& Bernstein, I. R. (1994). Psychometric theory (3rd ed.).

Powel, R. R. (1997). Basic research methods for librarians (3rd ed.). Greenwich, CT: Ablex.

Sacks, C. H., \& Bellissimo, Y. (1993). Attitude towards computers and computer use: the use of gender. Journal of Research on Computing in Education, 26(2), 256-269.

Sivathaasan, N., \& Velnampy, T. (2013). Use of electronic information resources and academic Performance of university teachers: A case study. European Journal of Business and Management, 5(14), 46-52.

Shuling, W. (2006). Investigation and analysis of current use of electronic resources in university libraries. Library Management, 28(1/2), 72-88. http://dx.doi.org/10.1108/01435120710723563

Velnampy, T. (2006). Association among personal demographic variables and incentive systems in Sri Lanka. Proceedings of the $3 \mathrm{rd}$ international conference on business management. Colombo: University of Sri Jayewardenepura.

Young, P. R. (2001). Electronic services and library performance measurement: a definitional challenge. Paper presented at the 4th International Conference, Northumbria.

\section{Copyrights}

Copyright for this article is retained by the author(s), with first publication rights granted to the journal.

This is an open-access article distributed under the terms and conditions of the Creative Commons Attribution license (http://creativecommons.org/licenses/by/3.0/). 